\title{
DEFENCE BUDGET AND MILITARY SPENDING ON WAR AGAINST TERROR AND INSECURITY IN NIGERIA: IMPLICATIONS FOR STATE POLITICS, ECONOMY, AND NATIONAL SECURITY
}

\author{
Dr. Temitope Francis Abiodun \\ Institute for Peace and Strategic Studies, Faculty of Multidisciplinary Studies, \\ University of Ibadan, Ibadan, Nigeria. \\ E-mail: abiodun.temitope3@gmail.com \\ Dr. Adepoju Adeoba Asaolu \\ Department of Finance, Faculty of Management Sciences, \\ University of Benin, Benin-City, Nigeria. \\ Anthony Ifeanyichukwu Ndubuisi \\ M.A. Student, Institute for Peace and Strategic Studies, \\ Faculty of Multidisciplinary Studies, University of Ibadan, Ibadan, Nigeria.
}

\begin{abstract}
Sound financial management of a state's security sector remains the key to efficient and effective security forces capable of responding to the citizens' legitimate security. The huge budgetary allocations for defence or military in Nigeria annually remain higher than budgets of all other West African states' defence/military operations combined together in all ramifications. But one would be dismayed that with the usual bogus defence budgets in Nigeria, the attendant effects on her political and socio-economic stability coupled with peace and security still fall far below ebb. The study therefore examines the reasons insecurity still persists in Nigeria despite huge budgetary allocations to defence and military spending on war against terror and insecurity in the last one decade, and implications for state politics, economy and national security. The study employed a progressive theory of public expenditure while it relies on both primary and secondary sources of data. The study in its findings reveals that despite huge spending or expenditures on military operations within the years, the security of the state remains deteriorating as a result of bad governance, corruption and non-transparent procurement activities, poor leadership, and lack of defence strategies among others; thereby creating some loopholes in national politics, economy and weakened national security respectively. The security situation remains worsening; Boko haram attacks in the northeast, armed banditry in northwest, kidnapping in all parts of the country, militancy in Niger Delta and Biafran agitation for secession in the country. The study, therefore, recommends that Nigerian government should endeavour to: shun corruption; ensure good governance, transparent procurement processes; and adopting defence strategies in compliance with global best practices towards ensuring a stable and secured society.
\end{abstract}

Keywords: Ministry of Defence, military budget, terrorism, national security. 


\section{Introduction}

Nigerian military spending in the last one decade is quite high and in most cases unnecessary. The reason is that in most cases what is often considered military expenditure is not actually directed for defence against external aggressions or enemies but rather against internal dissent, which in any case leads from poor economic conditions of people and ineffective governance. Military expenditure has not usually been connected to economic satisfaction in macro-economic analysis. In numerous instances, military spending which to a significant extent is as well taken to mean defence of security expenditure; and this has been tagged a "public good", the necessity and value is unanimously agreed upon or acceptable without further questions (Julius, 1992). Defence means a public good; it is designed by and for the society. Defence is different from private goods that are produced in the market in that it is consumed by every citizen proportionally whereas private commodities are consumed individually and specially by those who buy them (Julius, 1992).

Therefore, it is an axiom that defence or security of a state all over the world is instrumental to its overall developments; this could be agreed upon that military organization is known to be the most imperative institution in a given state; not only because it posses the mandate to protect the state's territorial integrity but also its internal cohesion. A nation's military is an institution that is approved to deploy coercive instruments, and use of weapons, in defending the state by waging war against any perceived threat (United States Armed Forces, 2017). In the same vein, the US military is deemed to have appeared under five different units of: Navy, Marine Corps, Air Force, Army, and Coast Guard respectively. As designed, every unit or branch of the United States' military posses its own outstanding mission within the overall mandate of United States of America's security. And the Secretary, Department of Defense (DoD) however, has control over the States military while the US President remains the Commander in Chief of Armed Forces, and takes all final decisions. This definition simply states the composition, duties and leadership of the military in the United States of America respectively (United States Armed Forces, 2017).

Furthermore, the following terms; armed forces, defence, security, arms, war, soldiers are important in understanding the nature of the military. It is of known fact that functions of the military are majorly to ensure the peace and security of a state. However, the Nigerian military has remained highly relevant and strategic since post-independent era, and prior to the period the nation successfully transited to democratic setting, ushering in the Olusegun Obasanjo's administration in 1999 (International Crisis Group, 2014). Despite the huge funds built into the defence budget in Nigeria, it is unfortunate that the military performance still remains seriously poor and uninteresting, thereby fuelling all sorts of insecurity and suppression of civil society in the country. It is surprising that immediately the country got transited to civilian or democratic rule in 1999, it is widely observed that the political space got more broadened, giving room for various violent agitations, putting more pressure on Nigerian military. In the South-South region, there are militants' agitations and ritual killings; in southeast, there exists Biafran agitations for secession and call for a sovereign state, northeast, there is armed banditry, Boko haram terror in the northeast and kidnapping has remained a "huge and lucrative business" in all parts of the country (Abiodun, Opatoki, Adeyemo and Obi, 2020). 
The study therefore, intends to investigate the amount already expended on military institution and security in Nigeria within the stated period; factors militating against huge defence/military budget performance; interrogate the implications on politics, economy and national security; and make some recommendations towards the country to normalcy. The study adopts secondary sources of data and materials while it employs a descriptive analysis to provide adequate response to the research questions raised.

\section{Theoretical Framework}

\section{The Progressive Theory of Public Expenditures}

The theory was espoused by an American writer and public finance analyst, Mabel Walker in her work Municipal Expenditures prior 1920, paying attention to the problem of distribution of expenditures. The theory states that developmental nature of society and government is an important tenet of progressivism; and distribution of expenditures or design of budget process in a larger society (Walker, 1920). The theory is one of the earliest attempts to develop a positive budget theory. It aids in the use of progressive ideals as part of social and intellectual thought. Walker's purpose was to provide a theory based on economic thought, particularly aspects of marginal utility, to be tested through statistical data analysis sufficient to be descriptive. Walker also intended to provide theory to aid in decisions for allocation of government expenditures. Mabel Walker (1937) reviews the theories of public expenditure and devises a method for ascertaining the tendencies in distribution of expenditures on the assumption that the way would be pointed to "a norm of expenditures that is consistent with the state of progress at present achieved by society" (Key, 1987). She focused her attention on municipal administration, particularly the expenditures of city governments. The problem of city government that drew Walker's attention was not the distribution of expenditures in a single city or the way a city carries out the budget process, but a larger question of whether all cities have similar budget distributions. Walker set about to determine if there was a distributional norm by category of municipal government expenditure.

Walker recognized the difficulty for politicians and budget clerks to decide if one or another public object has greater claims. The developmental nature of society and government is an important tenet of Progressivism. The Progressive political movement, or Progressivism, was a middle-class reform sentiment characterized by use of informed, moderate, and complex thought with concerns for urban reform, labor and social welfare, and interests of consumers. Progressives felt the responsibility to organize, legislate, and administer to address urban social problems. Theory is the use of progressive ideals as part of social and intellectual thought (Lewis, 1952). Like the idea of social Darwinism, the progressive philosophy also holds a core value of a society that develops and improves with the help of government as the agent to produce this change (Lynn and Wildavsky, 1990).

The theory's preconditions for a progressive public spending needs to be set forth; first or foremost, there is a developmental nature of states, the believe that government in a country actively seeks to improve reaching a level of excellence in maintaining the defence and security in all ramifications. Also, it was assumed that the services and methods used by public officers (government) were evolving for the better, and that public officers could manage this development to a higher level of security in a state, existence and quality of life. Moreover, it 
was believed that the most progressive states that are managed by rational leaders would not accept anything less than the minimum level of service or national security. Instead, they seek to achieve a high level of services or national security, hence the need to increase the budgetary allocations to defence and military institutions in Nigeria.

\section{Methodology}

The study employed the use of both quantitative and qualitative research methods with significant reliability index. Primary data sources included copies of questionnaire administered on respondents while a reasonable number of respondents selected with the use of purposive sampling technique was slated for interview because they are experts and knowledgeable on defence and security, and also budgeting and financial management. The sources of secondary data heavily relied on secondary materials obtained from the: internet sources, the Ministry of Defence (MoD), Central Bank of Nigeria (CBN), World Bank, United Nations (UN), Budget Office and the Appropriation Act of the National Assembly, the existing literature on the theme such as books, internet, journals, newspapers, magazines, periodicals. In the course of the study, the researchers made use of the libraries of: Adekunle Ajasin University, Akungba-Akoko and University of Ibadan, Nigeria respectively; to construct the impact index of the military budget and spending on political, socio-economic stance and national security, while the descriptive analysis was used for the analysis.

\section{Limitations of the Study}

The time for the study was short, only three hundred and sixty (360) hours was available to gather the data from the primary respondents due to fear of arrest by military officers as the issue was generating much tension in the country at that particular time. The researchers found it more difficult to generate adequate data from the Ministry of Defence and military body. In addition, the increasing spate of killings and insecurity being perpetrated by armed bandits coupled with Boko Haram insurgents did not go down well with the citizenry, thereby putting pressures on the military institution.

\section{Historiography of the Military Institution in Nigeria}

The historiography of Nigerian Military institution is known to be traceable to the elements in colonial period (McKaughan, 2016). However, the initial Nigerian regiment's origin lies in the elements of the Royal West African Frontier Force (RWAFF) that was inaugurated in January 1914 during the reign of colonial masters that ruled the country via an indirect system. The Nigerian Regiment of the Royal West African Frontier Force (WAFF) was renamed the Nigerian Military Forces and in April 1958, the colonial government of Nigeria took over from the British War Office control of the Nigerian Military Forces (Library of Congress Country Studies, 2018). The Regiment troop that actually fought during the Second World War (WWII) the soldiers were mainly recruited through the Northern Emir in Nigeria. Most of the recruited soldiers were deliberately sourced from the martial and from the provinces known to be minority in northern and southern Nigeria: the Tiv of Benue, Dakokori of Niger, Numan of Adamawa, and Kanuri of Bornu respectively and from the Calabar, Ogoja and Rivers (Aguda, 1991). This trend of recruitment existed until World War II when requests for skilled tradesmen and technicians came up as chances for more southerners. Apart from fighting the WWII, the troops were also deployed to suppress various internal interregnums at that time: the Egba revolt of 1914, Aba 
Journal DOI: 10.46654/ij.24889849

Women riot of 1929 among others. The massive expansion of the Regiment led to the establishment of temporary camps all over Nigeria. This created civil-military tensions with local civilians who often complained of atrocious and brutal conduct on the part of the recruits (Library of Congress Country Studies, 2018).

Moreover, in 1949, the General Officer Commanding-in-Chief of the RWAAF, General Nicholson, proposed that a West African Military Academy for West Africans be put in place, and was the first opportunity whereby a significant contribution of Nigerian political leaders in military matters apart from the initial efforts of emirs in recruitment process, became felt. Though the gesture was strongly opposed by numerous political leaders in the country for fear that graduates of such an academy would not be viewed as having the same level of training as British officers that were trained in Great Britain (Library of Congress Country Studies, 2018). Therefore, the Nigerian military got fully metamorphosed into a full military force after the country's independence in 1960, and got itself engulfed in state's politics in 1966; the period during which some young military officers attempted to overthrow the democratic government in the country. Power was, thereafter, handed over to the military after the failed while the disagreements as to who ascend power or succeed invariably resulted to a civil war between 1967 and 1970 and this had negative implications on the development of the Nigerian military institution in all ramifications (Library of Congress Country Studies, 2018).

However, the current or modern Nigerian military institution encompasses: the Nigerian Army (NA), Nigerian Navy (NN) and Nigerian Airforce (NA) while institution is administered by the Federal Ministry of Defence respectively. The institution of military as existed in most other states excludes the police, and all other uniform and non-uniform security outfits in Nigeria. According to the Ministry of Defence, the statutory responsibilities of the Nigerian military are as follows:

- maintenance of personnel of the Nigerian Armed Forces in a state of combat readiness on land, sea and air;

- maintaining the existing arms and men to meet needs of internal and external security;

- seeing to the welfare of officers of the Armed Forces in terms of training, accommodation, health care and other benefits aimed at boosting their morale;

- promoting the capabilities and sophistication of the country's defence industries, so as to reduce the country's dependence on foreign sources of supply;

- enhancing security in the African continent by promoting a collective defence system through bilateral, sub-regional and continental co-operation;

- contributing towards global peace and stability through the United Nations Organization (UNO) the African Union; (AU) and the Economic Community of West African States (ECOWAS); and

- being responsible for the formulation and execution of the National Defence Policy regularly.

From the onset, it is usually observed that the military institution in a state could be deployed by any totalitarian government against the popular will of the people; this is highly 
disadvantageous of the institution in all ramifications. However, administering a military institution to meet the global standards and effectiveness, there is dire need for adequate funding and before funds are disbursed within the governmental process, there is also the need for a budget to be made by the Defence Ministry in a state. According to McKaughan (2016), budget refers to a quantitative expression of a plan for a defined period of time. It may also involve planned sales volumes and revenues, resource quantities, costs and expenses, assets, liabilities and cash flows (McKaughan, 2016).

\section{Conceptual Clarifications}

\section{Concept of Defence/Security}

The basic responsibility of a nation's government involves defending and keeping its citizens safe at all times. And Thomas Hobbes submits, only the state has the wherewithal to guarantee defence, security and prevent the society from anarchy, through its government is deemed fit to have provided adequate security (Gaskin, 2016 as cited in Abiodun, Adedokun, Owoyemi and Kehinde, 2020). Pursuant to this, Abiodun et al (2020) agree that security usually remains a dynamic condition which encompasses the relative ability of a state to counter threats to its core values and interests. In the same vein, the security of a state is premised on two significant pillars which are: the maintenance and protection of the socio-economic order in the face of internal and external threat; and enhancement of a chosen international order that suppresses a threat to core values and interests, and also to the domestic order (McKaughan, 2016).

However, security and defence mean an all encompassing situation indicating that a territory must be secured by a group of armed forces; and that the sovereignty of the state must be adequately guaranteed by a democratic and patriotic government, which in turn should be protected by the military, police and the people themselves; and that the people must not only be protected from foreign attacks but also from bad implications of internal distress which includes: unemployment, hunger, starvation, diseases, ignorance, homelessness, environmental degradation and pollution (Achumba, Ighomercho, Akpor-Robaro, 2013). From the time immemorial, security is all about people and without course to the security of the individuals, security is null and void. According to Abiodun and et al (2020), Nigeria's security should be based on a holistic look that views the citizenry as the primary beneficiaries of security and developmental benefits a state offers. Therefore, Nigeria's security involves efforts to strengthen the capacity of the Nigerian government towards promoting its interests to contain internal and external attacks, crimes, kick out corruption, promote growth and development, and improve the welfare of life of citizenry.

In his own explanations, Wilson (2014 as cited in Abiodun, Oladejo, Adetunberu, and Nwannenaya 2019) highlighted the various forms of national security to include: political security, economic security, energy and natural resources security, homeland security, cyber security, human security, and environmental security respectively. Without mincing words, defence and security are generally taken to be about the condition of feeling safe in a state, the protection and preservation of core values and the absence of threats to the existing values. The concept amounts to freedom from danger or from threats to a country's ability to protect and develop itself, and also promote its cherished values and legitimate interests (Abiodun, 2016). Security/defence is a major human desire; it is significant to the extent that absence of it renders 
people ineffective in all sense. Abraham Maslow's work on human needs also ranked security as second (next to physiological needs) in the hierarchy of human needs. That is why Abiodun (2016) submits that security of lives and property is exclusively the preserve of the state but the dynamics of the world today has clearly revealed that security is the responsibility of all.

\section{Concept of Budgeting}

Budget is a vital instrument in governance just as blood is vital to life. Any government desiring to succeed should ensure adequate plans are put in place. Budgeting is not an end in itself but it is a means to an end (Bove and Brauner, 2016). Planning in the context of government administration involves the determination of the future overall goals or objectives, preparing policy statement and monitoring of result (CIMA, 2015). Budgeting in the public sector has become an annual ritual which is characterized with repetitiveness. Budgeting is the process of creating a plan to spend money; the spending plan is called a budget. The Chartered Institute of Management Accountants (2006) in the same vein conceptualizes budget as a plan (quantitative and monetary) that is prepared and approved before a defined period of time usually showing planned income to be generated and, or expenditure to be incurred during that period and capital to be employed to attain a given objective (CIMA, 2006).

It is of the opinion that a budget gives a glimpse or picture of expenses and revenue expected in a defined year through painstaking estimations in view of an optimal result. A budget could also be defined as a document from the government that sums up its revenue and expenditure for a fiscal year, which runs from the beginning of the year January to the end of it December (Suleiman, 2015). Succinctly put therefore, budget is the financial plan that describes expected revenues and disbursement for a period of time usually one year (it could be granulated further into months, quarter or bi-annual based on needs). In other words, it is an instrument for measuring income and expenditures. Budget is an economic process which converts state development plans and priorities into a programme of action (McKaughan, 2016).

Broadly speaking, budgets could be cash budget, capital budget and expenditure budget, among others. Budget is built around the appropriation provisions of 1999 constitution (sections 81 and 82) (Congressional Budget Office, 2001). Budgets accommodate the principle of Annuity (annually or prepared yearly), the rule of Lapse (an effective financial control window; unspent portion of the budget should be returned to the government or public treasury (coffers) even if it is to be added to the following year's planning), Fiscal Discipline ( budget should be balanced and show relevant congruency between income and expenditure), Inclusiveness (includes all government incomes and expenditures, this assists in evaluating the trade-offs between different policy options), Accuracy (budgets although are forecasts, the onus is on the Ministry of Finance to assist with the data and other materials needed by various departments and sub-units, the estimates should be accurate and precise as much as possible), Transparency and Accountability (main two indicators propounded by the United Nations (UN); this has to do with the parties involved to observe the ethics of probity) (CBSE Guide, 2007-2017).

However, budgets could be balanced ( where incomes and expenditures are the same or equal) or surplus (where income generated is more than expenditures) and deficit (where income falls short of expenditure, that is, expenses are higher than actual income); this could help the 
government to identify the damage of economic recession on the labour market and guides the government to expense on public or social welfare, on the flipside however, it could increase debt burden on the government as well as marked imprudence in some quarters (CBSE Guide, 2007-2017).

\section{Concept of Military Budget}

Military budget or expenditure in a state is synonymous with defence budget. It is the amount of financial resources voted by a state (nation) to nurturing and conserving armed forces and other essential needs required for defence purposes; this includes, but not limited to guns, military jets, military hardware, logistics and finance for special missions. Meanwhile in the conventional parlance, military budget is to finance a critical service area by the government and not an income (revenue) generating platform (McKaughan, 2016).

In the same parlance, military expenditure is conceptualized by the North Atlantic Treaty Organization as a process made up of current and capital expenditures of the military such as defence and other government agencies involved in military projects, finance for peace keeping, paramilitary (those trained and equipped with military for its operations) and military space activities (Apanisile and Okunlola, 2014). However, the amount a state designs for her defence could be the proactive measures taken against perceived threats or external aggression; it also indicates the ability of the country involved to fund it (Sam, Aude, Pieter and Siemon, 2016). Pursuant to this, a state must deem it fit taking into cognizance the size of her economy, debt servicing, recurrent and capital expenditures, and the willingness of the government to finance such military operations. However, several states fail to capture expenditures on internal law enforcement agencies and would-be injured personnel rehabilitation in the main defence budget (Apanisile and Okunlola, 2014).

\section{The Budgeting Process in Nigeria}

The practice of budgeting in government as it is now understood originated in the central government of Great Britain. It later develops gradually as a result of parliament's struggle to obtain control over the finance of the crown. It was first understood in 1920s as a tool to manage costs and cash flows in large industrial organizations (Johnson, 1986). The annual budget is a form of plan, which sets out a programme of projected government expenditure geared towards achieving some policy targets (Congressional Budget Office, 2001). Such targets would be within the confines of some available policy instruments and assumptions regarding projected revenue. Such policy target and instrument need not be limited in duration to conventional period of one fiscal year normally covered by annual budget. However, whether such policy and instrument are carried over from previous year or not or are capable of extending to subsequent years, it is often assumed that the particular period or year in focus represents the budget year (Glamour, 2005).

Essentially, the Nigerian budgetary process is captured in the diagrams and summary as illustrated thus: 
Journal DOI: 10.46654/ij.24889849

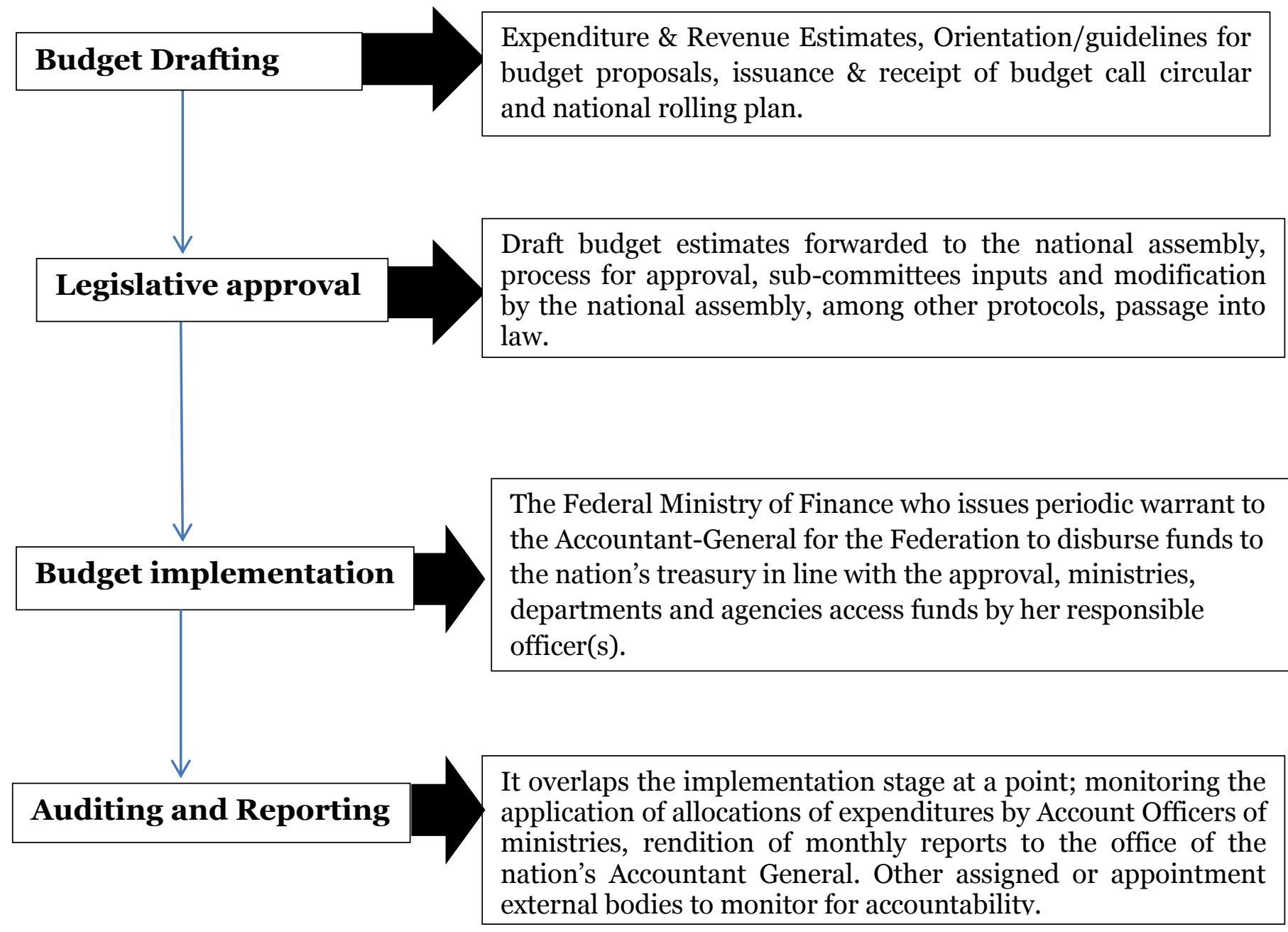

Source: Central Bank of Nigeria; and CBSE Guide (2007-2017)

\section{Analysis of the Process}

For adequate comprehension, the study indicates that defence/military budget process follows the same four process stages with the inclusion of strategic procurements under implementation. Military budget process gets designed and arranged by the Budget Planning and Implementation Committee that is usually headed by a Permanent Secretary in the ministry and other Directors of service departments, made up of civilians, the ministry's Director of Finance, Heads of Finance of the existing three (3) services and a representative of the Defence headquarters. The only outstanding feature of the defence ministry when compared with other ministries remains the fact that; the decision-making stage on strategic procurement by the military institution is usually led by the Chief of Defence Staff (CDS) at the defence headquarters (Omotoogun and Oduntan, 2006). 


\section{Chronology of Defence (Military) Budget and Spending in Nigeria 1999 - 2019}

\section{i. $\quad$ Military Budget (1999 - 2009)}

The year 1999 marks the end of military administration in the country, giving room for transition to democratic government after several years of military rule in the state. Table 1 below shows the military budget for the period:

\section{Table 1}

\begin{tabular}{|c|c|c|}
\hline \multicolumn{3}{|c|}{ Military (Defence) Budget in Nigeria (1999 - 2009) } \\
\hline Year & Amount in USD \$ Billions & $\begin{array}{l}\text { Percentage (\%) in Gross Domestic } \\
\text { Product (GDP) }\end{array}$ \\
\hline 1999 & 0.49 & $0.86 \%$ \\
\hline 2000 & 0.37 & $0.54 \%$ \\
\hline 2001 & 0.57 & $0.78 \%$ \\
\hline 2002 & 0.9 & $0.95 \%$ \\
\hline 2003 & 0.59 & $0.57 \%$ \\
\hline 2004 & 0.64 & $0.49 \%$ \\
\hline 2005 & 0.67 & $0.40 \%$ \\
\hline 2006 & 0.78 & $0.35 \%$ \\
\hline 2007 & 0.97 & $0.37 \%$ \\
\hline 2008 & 1.62 & $0.49 \%$ \\
\hline 2009 & 1.5 & $0.51 \%$ \\
\hline
\end{tabular}

Source: Central Bank of Nigeria; and Suleiman (2015).

During the period, it is observed that budgetary allocations to military are rather too low in the country as a result of one reason or the other. 
Journal DOI: 10.46654/ij.24889849

Vol. 6, Issue 7 (July, 2020) | www.ijaar.org

Article DOI: 10.46654/ij.24889849.s6713

\section{ii. $\quad$ Military Budget (2010 - 2019)}

Table 2 reveals the military (defence) budget for the period 2010 - 2019:

Table 2

\begin{tabular}{|c|c|c|}
\hline \multicolumn{3}{|c|}{ Military (Defence) Budget in Nigeria (2010-2019) } \\
\hline Year & $\begin{array}{l}\text { Amount US Dollars (\$) } \\
\text { Billions }\end{array}$ & $\begin{array}{l}\text { Percentage (\%) in Gross Domestic } \\
\text { Product (GDP) }\end{array}$ \\
\hline 2010 & 1.99 & $0.54 \%$ \\
\hline 2011 & 2.38 & $0.58 \%$ \\
\hline 2012 & 2.32 & $0.50 \%$ \\
\hline 2013 & 2.42 & $0.47 \%$ \\
\hline 2014 & 2.36 & $0.41 \%$ \\
\hline 2015 & 2.07 & $0.42 \%$ \\
\hline 2016 & 1.72 & $0.43 \%$ \\
\hline 2017 & 1.62 & $0.43 \%$ \\
\hline 2018 & 2.04 & $0.51 \%$ \\
\hline 2019 & 2.15 & $0.53 \%$ \\
\hline
\end{tabular}

Source: (Central Bank of Nigeria; and Library Congress Country Studies, 2018)

Surprisingly, it is evident that the period, 2010 - 2019 unavoidably witnessed an upward increase in military (defence) budgetary allocations and spending in Nigeria in order to renew the military efforts towards decimating the activities of Boko haram terrorists in the northeast; checkmate the upsurge of militancy in southeast; armed banditry in northwest; other kidnapping cases across the country; and to procure some sophisticated or modern military hardware and weapons/ammunitions. The budgetary increase was approved by the National Assembly in order to boldly correct the anomalies of inadequate funds for defence and military operations in Nigeria; hence the continual offensive attacks by the Boko haram sect in the region. 


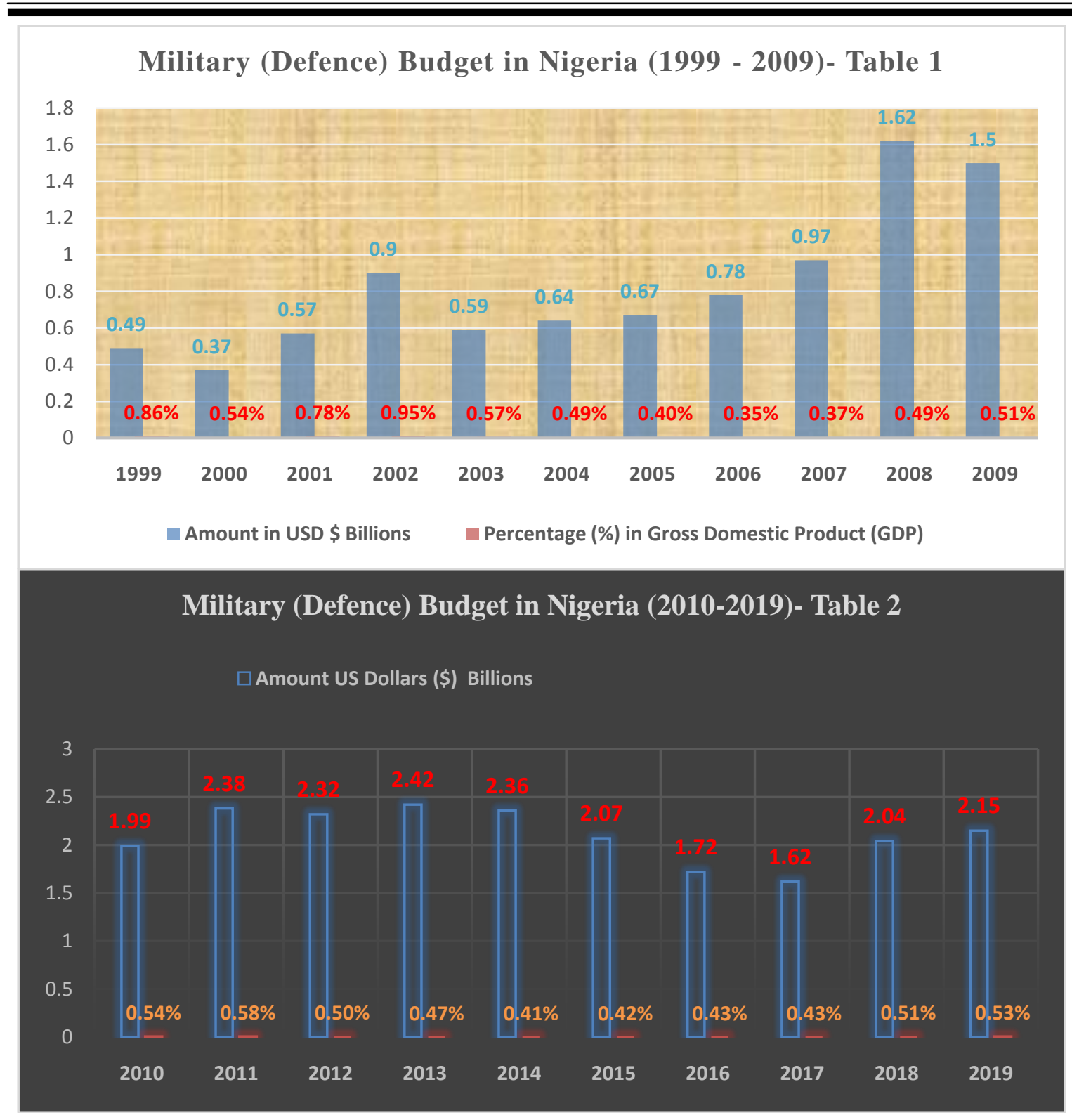

Source: (Central Bank of Nigeria, CBN and Ministry of Defence, Abuja, Nigeria)

\section{Causal-Factors Triggering the Increasing Terror and Insecurity despite the Huge Budgetary Allocations and Military Spending in Nigeria}

The study reveals that the Nigerian government has improved budgetary allocations to the defence or military institutions in the last one decade but despite the gesture, there is persisting or unending insecurity in the state as a result of the following factors: 
Journal DOI: 10.46654/ij.24889849

\section{Corruption in the Security Sector}

Corruption has remained one of the major banes of insecurity in Nigeria due to diversion of public resources. Many Nigerian military personnel, politicians and other elites have enriched themselves through diversion of funds meant to fight terror and insecurity in the country. The Nigerian military budget appears to having some inappropriate expenditure items and budgets items that are not justifiable, this lead to misallocation or non-allocation of such funds. Much of these funds is said to have disappeared through kickbacks, payments to "ghost soldiers" who do not exist or via no-bid contracts resulting in the inflated spending that benefits politically connected contractors. The study further stressed that it is ultimately the frontline troops who suffer from this kind of corruption. Unequipped soldiers have been left killed in ambushes or have simply fled the battle-field when faced with the superior firepower and equipment of the terror group (Boko haram) while payments are not made to the soldiers on ground (Field Survey, 2020).

There is duplication of expenditures using different headings by personnel in charge of funds in the Ministry of Defence. This practice cuts across most of the institutions under the ministry. For instance, in one of the years under review, only N55.4 million would have been spent on office maintenance but this maintenance was duplicated into four sub-categories, thereby using the opportunity to siphon or embezzle the funds. In the same vein, the budgetary allocations to the Nigerian Army (NA); Nigerian Navy (NN); and Nigerian Air Force (NAF) were all inflated using different expenditure headings in 2014, 2015, 2016, 2017, and 2018 respectively. In the budgets where they appeared, they assigned huge amounts of money actually needed to face the mounting security challenges facing the country but diverted for personal use in the long run (Field Survey, 2020).

\section{Unhealthy Rivalry among the Military Forces}

In the same vein, the study observed there is security failure as a result of unhealthy rivalry among the military components: Nigerian Army (NA); Nigerian Navy (NN); and Nigerian Air Force (NAF) and other security agencies as this militates against winning the war against terror and insecurity in Nigeria, most especially in the north-eastern region. As result of this, there is sabotage the areas of: mapping strategies, diffusion of landmines and security intelligence sharing. Also when the armed forces and paramilitary agencies are not well equipped with modern fighting and security gadgets and their welfare is not given priority attention, they may not want to make any sacrifices for the nation. All of these factors point to a passive national security team that is not really committed to fighting or stopping violence and terror in the state.

\section{Poor Leadership and Absence of Good Governance}

The military in the country has the sole responsibility to protect the territorial integrity of Nigeria. The military needs a lot of funds to carry out this assignment; hence Nigeria tries all it can to make such funds available. But from the results of the findings, there is an indication that the Nigerian military is not deploying such funds in the right direction. It is mainly involved in procurement of office goods and services and building structures for its enjoyment. This is evident to the happenings in 2014 when Boko Haram was having its way in killing innocent 
Journal DOI: 10.46654/ij.24889849

Nigerians; the military was busy spending over N7 billion in overseas tours (Field Survey, 2020). Corruption and bad leadership have been identified as the leading causal factor of insecurity in Nigeria. The resources and budgeted funds meant for the general welfare of military personnel at the war fronts are stolen and diverted to personal use by a few individuals in Nigerian government and military institution, while bad policies and programmes initiated and implemented by successive leaderships, both military and civilians, only succeeded in worsening and destroying the security situation in the country (Field Survey, 2020).

\section{Effects of Military Coups and Unruly Conduct of Military Personnel}

It has been observed that using the military to quell internal conflicts and to restore order in Nigeria since military rule has caused more insecurity in all ramifications. In fact, this undermines the legitimacy of the military mission, as well as failing to quell the escalating violence in the country. The unruly behaviours and conduct of military men only worsen the security situation the more; this is as a result of their (military) lack of professionalism - soldiers often intimidate and coerce civilians or innocent citizens. They also engage in corruption and extortion, most especially at military checkpoints where they are supposed to war against insurgents in northeast. Moreover, military men subject Nigerians to psychological and emotional abuse; while others engage in blatant and flagrant acts of sexual and gender-based violence in the state. All these acts would never checkmate the spate of growing insecurity in the country (Field Survey, 2020).

\section{Politicization of Security and Lack of Military Commitment in the Country}

The study reveals the factor of undue politicization of the security situation in Nigeria by the military forces. The Nigerian military has abandoned its primary assignment of the defence sector or military institution which includes the security, defence and fortification of the state from all sorts of both internal unrest and external aggression/attacks. This is true because the primary assignment which involves security/defence of the state has become highly politicized and now made a profit-making venture in all ramifications. It is disheartening that the war against Boko haram terror started before 2009 and up till present moment, Boko haram attacks have become in many folds, still raging on in northeastern part of Nigeria (Field Survey, 2020).

\section{Late Passage of Annual Budget by the Nigerian Government}

The respondents in the study also accused the Nigerian government of disregard for quick preparation and passage of national budget, late release of capital vote, and selective implementation of budget. The issue of poor performance of budget is noticeable virtually in the country. This is evident in our infrastructural decay and this has virtually impacted negatively in the slow pace of development specifically in terms of capital project, physical infrastructure, political instability, projects abandonment, deployable roads, high rate of un employments, insecurity, to mention but a few.

\section{Lack of Transparency in Procurement Process in the Military Sector}

Lack of transparency in particular results in high vulnerability for corruption, most especially in arms procurement processes. The procurement of military arms or weapons in Nigeria is usually shrouded in secrecy; therefore, old-fashioned items are ordered and purchased by the government and military institutions instead of purchasing sophisticated weapons and 
ammunition that are supposed to be deployed to crush the terrorists. There is absence of transparency in the process and transparency has to do with probity and accountability of the military to both the government and the people at large. However, most developing countries are lacking on this crucial aspect of military budgeting and implementation due to certain aspects of expenditures shrouded in clandestine manner or not adequately recorded. Therefore, transparency goes beyond ordinary public announcements of all the items on the budget, but rather, it has to do with procedural visibility and clarity which are facilitated by media investigations, and parliamentary oversight scrutiny (Field Survey, 2020).

\section{Extra-Budgetary and Off-Budget Military Spending}

However, extra-budgetary spending refers to a situation in which spending on the military from other sections of the nation's budget. This includes the science or infrastructure budgets, special Presidential funds and loans whose repayment comes from the Ministry of Finance; such spending is not clearly and properly disaggregated and reported, therefore making it very difficult to disentangle all figures of military spending in a state. In the same vein, offbudget spending hails from outside the state budget altogether and this include dedicated natural resource funds used for arms purchases, payments from the private sector for military or security activities (Field Survey, 2020).

\section{Poor Budget Implementation in Nigeria}

There is perennial gap between budgetary estimates and implementation as a growing concern and a contributory reason for poor economic development and reign of insecurity in Nigeria. It is no more unusual to hear of frequent low budget implementation in the ministry of defence and military, leaving one to wonder if the organization's budgets are usually designed to be partially implemented. The avalanche of military arms and ammunitions that are supposed to be purchased is left not carried out. That is one of the reasons scores of Nigerian military men are being killed like fishes by the Boko haram terrorists in northeastern region of the country (Field Survey, 2020).

\section{Lack of Monitoring, Control and Auditing}

Another issue is weak monitoring, controls and audits in the military or defence institution, thereby facilitating corruption and waste. Budgeting for the military sector in Nigeria and Africa at large is found with extremely weak or low capacity for controlling spending in many cases. Various public scrutiny institutions, particularly, audit agencies, anti-corruption bodies and Parliamentary Public Accounts Committees are usually reluctant to investigate the military or prevented from doing so (Field Survey, 2020).

\section{Implications of Defence (Military) Budget and Spending for State Politics, Economy and Security}

The study reveals the implications of defence or military budget and spending in Nigeria in recent times on political activities, economy and national security thus:

\section{State Politics}

During the last one decade of increased budgetary allocations to defence (military) institution, political upheavals have been on the increase in Nigeria; and there now exists what is 
termed "budget of national politics". Politics in Nigeria nowadays, involves huge spending and it is now the most lucrative profession in the country. Nearly all the citizenry in Nigeria now wish to participate or get engaged and involved in politics, believing that they become rich or wealthy within few months when appointed or elected into political offices (Field Survey, 2020).

There are security problems and instability in the country despite huge military budget, and in this quagmire, the politicians in Nigeria (Ministers, political appointees, and Executives both at federal and state levels) and most especially the lawmakers have come up with a more centralized process capable of establishing their own priorities towards ensuring monies go into their personal pockets. The Minister in charge of the Defence Ministry and heads of security agencies get certain percentages from the funds allocated to their ministry and agencies as they remain the "supremo inter parels" in the organizations (Field Survey, 2020).

In the same vein, defence/military budgets are being padded annually. This is true in the sense that various extra items are injected into the budget to ensure there are extra funds to be embezzled during implementations. For instance, the lawmakers that are appointed to the Senate/House of Representative Committee on Defence/Military Affairs have become wealthy from the "goodies' realized as a result of various over-sight functions they carry out on military and security agencies' matters (Field Survey, 2020).

In addition, the proliferation of small arms and light weapons, vote-buying, and do-or-die politics are now institutionalized in the state as funds from the huge budgetary allocations to military/defence institutions are being diverted into politics with strong connivance between the ruling "Executives (political office holders)" and heads of Nigerian security agencies or the military service chiefs. Most of the time, the Nigerian government diverts part of the funds in the budget for political campaigns and activities for their selfish interest and as well achieve their personal purposes as was the case under the then National Security Adviser to President Goodluck Jonathan, Colonel Sambo Dasuki. The funds meant for purchase of arms and ammunitions for the military were diverted (Field Survey, 2020). Most of these diverted funds are being used to spread small and light weapons being used by the "ordained political thugs" to unleash mayhem on innocent Nigerians during elections. Also, parts of the diverted funds are channeled into vote-buying by the ruling governments in Nigeria. That is the reason why electoral violence is on rampage during elections in the country. For instance, the recent gubernatorial elections in Kano, Osun, Kogi and Rivers States were nothing to write home about; it was full of violence and irregularities where many innocent citizens' lives were claimed (Field Survey, 2020).

Besides, the principle of professionalism on the part of military personnel in Nigeria is becoming dwindling as a result of their usual and indirect indulgence in politics. From the time immemorial, military is known to be indifferent to politics in a state but currently, opposite is the order of the day. The military men aid electoral frauds in the country having received largesse of kickbacks from the funds diverted into their pockets before elections. Apart from this, various political thugs, street urchins and mercenaries are being sponsored to undermine the national security (Field Survey, 2020). 
In the same vein, there has been a divergence from the primary assignment of the defence sector or military institution which includes the security, defence and fortification of the state from all sorts of both internal unrest and external aggression/attacks. This is evident in the sense that the primary assignment (security/defence of Nigerian state) has become politicized and profit-making ventures in all ramifications. The war against Boko haram terror has begun before 2009 and up till present moment, the offensive attacks still rage on in northeastern part of Nigeria, unending. The Nigerian military troops remain ranked the best and outstanding in Africa; there should not be any internal or external aggression they should not defeat within few a time, but it very disheartening that the security service chiefs in Nigeria have turned it to a business from time to time, the opportunity through which their personal pockets are being filled annually and periodically (Field Survey, 2020).

Apart from colonialism, which itself is authoritarian in inclination, militarism has shaped and impacted greatly on the nature and character of the Nigerian state. Its effects are visible in nearly all facets of the Nigerian life. This incidence poses a serious threat or challenge in the journey towards democratic consolidation in the state. This is evident in the sense that military men have turned themselves to "gods" or being above the law as a result of their undemocratic behaviours in the country; they arrest, drag, beat, maim and kill innocent Nigerians at will in the country. They have become lawless (Field Survey, 2020).

\section{National Economy}

The military has the sole responsibility to protect the territorial integrity of Nigeria. The military needs a lot of funds to carry out this assignment; hence Nigeria tries all it can to make such funds available. But from the results of the findings above, it seems that the Nigerian military is not deploying such funds in the right direction. It is mainly involved in wasting and squandering of the budgeted funds in procurement of office items and as well building structures for its enjoyment in all ramifications.

Therefore, the following are some of the implications of the situation mentioned above: The security of lives and properties in Nigeria will be compromised. This is because the military will not be strong enough to defeat security threats like the Niger Delta militancy, Boko Haram terror in northeast, armed banditry in northwest, and Fulani kidnapping and killing threats across all regions of Nigeria. In the same vein, when security is compromised, Nigerian citizens and residents would no longer find it easy going about their normal daily business activities due to fear of being killed or kidnapped. However, the state environment becomes more hostile and tensed up and this situation abhors progress of economic advancements (Field Survey, 2020).

Furthermore, insecurity as a result of these military spending deficiencies has given room for military and political leaders to promote crony capitalism and corruption at the detriment of vulnerable Nigerian citizens, foreign expatriates, and humanitarian service providers and poorly armed military personnel. To cap it all, probing is still ongoing as some of President Jonathan's political allies were indicted - this remains an indication of high level or depth of corruption in the country. Besides, insecurity in the land has strangulated the various business fortunes and environments and are tantamount to less economic productivities and its attendant poverty. State of insecurity also fans the embers of unemployment especially among the teeming youths in 
Nigeria as we all know that idle youths are highly vulnerable to crimes and other forms of delinquencies in the society. Also, as a result of the growing insecurity in the state, more budgetary allocations would be made for military operations/defence at the expense of other infrastructural and developmental activities that are supposed to benefit the lives of Nigerians (Field Survey, 2020).

\section{National Security}

Insecurity emanating from the deficiencies in financial management and military spending in Nigeria poses dangerous threats to national security in all ramifications. That is the reason northeast Nigeria has remained engulfed in Boko Haram attacks more than a decade, leading to loss of over 28,000 Nigerian lives (Field Survey, 2020).

Moreover, there has been trade-off situation between increased military budget and at the same time provision of social amenities for the benefit of the citizenry such as: motorable road networks, good health care, qualitative education, and stable electricity among others as a result of yearly increase in budgetary allocation to defense/military sector alongside with other state governments in Nigeria. Huge amounts are paid as stipends to military officers and members of Civilian Joint Task (CJTF) in response to Boko haram terror - this remains a gap in the country's developmental agenda; thereby fuelling insecurity in the country. That is the major reason the Nigerian government as part of its response to combat Boko Haram terror, increased the defense budget from N100 Billion Naira (\$625 million) in the year 2010 to N927 Billion Naira (\$6 billion) in the year 2011 and N1 trillion Naira (\$625 million) Naira in2012, 2013 and 2014 respectively at the expense of the one allocated to other sectors in the country (Field Survey, 2020).

Nigerian borders are now porous. Much more border problems have been created which have in turn affected the security situation in Nigeria. It is a matter of concern that Nigeria share a 1,497-kilometer border with Niger Republic, 85-kilometer border with Chad through Lake Chad and Nigeria's longest border line is the 1,690-kilometer border with Cameroon (Field Survey 2020). Research has revealed that the borderlines between Nigeria and other states in Africa have continued to witness several hostilities from illegal immigrants as a result of security failure.

It is as well no more an exaggeration that Nigeria has faced the most worrisome security threat in her existence ever in history after the Nigerian civil war, all attributed to the Boko Haram insurgency. So many lives have been lost due to this ugly situation. Accusations and counter accusations by various personalities, government functionaries and political parties have not yielded any positive result. It is obvious that wasteful and unscrupulous military budgets and spending in Nigeria have not been taken into account in the process of handling the nation's security problem (Field Survey, 2020). It is pointed out that the entire West African sub-region has been inundated with small arms and ammunitions which have in turn increased serious crimes in the region in all ramifications. In the same vein, military dominance has stemmed authoritarianism that has manifested in arbitrariness, command-and-obey syndrome, intimidation of civil rights, absence or no respect for the rule of law and due process as well as the 
emasculation of the judiciary through ouster decrees. This orientation also breeds intolerant political environment that still causes problem for democratic consolidation in the country.

It is surprising that the civic responsibilities such as voting during elections that are now exclusively disrupted by hooligans or political thugs in Nigeria as a result of small arms and light weapons proliferations following the failure of the military sector to do the needful in the country. It is also disheartening that numerous permanent Nigerian voter cards were seized from over 700 nationals of Niger, Chad, Cameroon and Mali who entered Nigeria illegally in 2014 due to the fact that there is increasing laxity and failure on the part of the Nigerian security agencies to guide or protect the state borders (Field Survey 2020).

The study indicates that illegal circulation of small arms and weapons is now order of the day in Nigeria. There have now been invented several ways of smuggling prohibited items in and out of the country. Illegal immigrants have created numerous strategies of illicit bordercrossing, and many weapons that are small, light and collapsible are packed at the backs of donkeys, camels and cows for easy smuggling into Nigeria. Similarly, arms are hidden in grains usually conveyed in large number via trucks, trailers, Lorries and old model pickup vans and jeeps which is unsuspected by security agents (Field Survey 2020).

There are incessant and prolonged violence, armed banditry, kidnapping by Fulani herders, communal clashes/conflicts, and Niger Delta militancy among others in the country. These civil unrests have displaced a lot of people who were compelled to migrate to neighbouring countries for safety. This is in line with what the Field Survey (2020) stated that majority of migrants are forced to cross borders as a result of lingering crisis in their places of origin. Also, a large number of Nigerians have been rendered homeless, displaced and become refugees as a result of the Boko Haram terror going unchecked in the northeastern region of the country. And many a time, the military institution in Nigeria has come out to dish out lies and propaganda that the sects' activities have been out-rightly decimated whereas it is not true (Field Survey, 2020).

\section{Conclusion}

It is very clear that the Nigerian military institution which transmuted from a colonial oppressive force to an agency of an independent state has been through many years of transformation. There have been huge budgetary allocations and spending for the military or defence sector in the country with hope that security of the state would improve but opposite been the usual case. The growing spate of insecurity, in Nigeria, therefore, is a result of the military failure in Nigeria. A less peaceful environment cannot produce economic progress and may continue to suffer retrogression and underdevelopment. The study has empirically analyzed the causes of poor budget performance and its implications in Nigeria. The result of the analysis shows that there is poor budgetary performance. The causes as shown by the result of the data analysis reveals that factors such as poor planning, budget indiscipline, fraud, lack of budget monitoring, delay in passage of budget, involvement in extra- budgetary activities, wasteful spending and lack of professional knowledge are all responsible. This has undoubtedly impacted on the performance of our government and consequently slows down economic development. 


\section{Recommendations}

The following recommendations are suggested by the study in order to avoid wasteful and corrupt eat-up of increased military budgets and allocations towards attaining stable security in Nigeria:

a. Avoidance of excessive, wasteful and corrupt military expenditures and procurement which requires high levels of transparency and accountability in military budgeting and procurement processes.

b. Another way out of this quagmire is for the military to cleanse its house and ensure the effective utilization of its funds and provide security to Nigerians.

c. Military budgeting and procurement processes should adhere strictly to government-wide financial management and oversight practices, with rigorously observed defence policy and planning framework. These include: strict adherence to public expenditure management (PEM) principles of comprehensiveness, discipline, legitimacy, flexibility, predictability, contestability, honesty, information, transparency and accountability.

d. There should be transparency of information on military spending, that is, to find out whether information on military budget and actual spending is readily available to members of the public, and the level of its reliability, details and total understanding of the information.

e. Also, the transparency of the process needs be put in place and this means to find out if budgetary decision-making is actually open and visible, with the reasons for such military spending clearly outlined and spelt out.

f. There must be adequate monitoring, control and auditing of defence budgets and military spending in the country to ensure the nation's security remains paramount.

g. There is need for election of good leadership and enthronement of good governance in the country that would have full commitment to the overall security and betterment of Nigerians.

\section{Acknowledgement}

We hereby acknowledge the input of all members of this team for their indefatigable efforts during this study. 


\section{References}

Abiodun, T. F., Adedokun, O.O., Owoyemi, E. A and Kehinde, O. S. (2020).Unlawful Killings of Civilians by Officers of the Special Anti-Robbery Squad (SARS) Unit of the Nigerian Police in Southwest Nigeria: Implications for National Security. African Journal of Law, Political Research and Administration ISSN: 2689-5102 Volume 3, Issue 1, 2020 (pp. 4964)

Abiodun, T. F., Opatoki, O. O., Adeyemo, D. T., and Obi, C. (2020). Assessment of Boko Haram Insurgents' Threats to Educational Development in the Northeast Nigeria: The Way Forward. African Journal of Social Sciences and Humanities Research ISSN: 26895129 Volume 3, Issue 1, 2020 (pp. 31-43)

Abiodun, T. F., Oladejo, O.A, Adetunberu, O., and Nwannenaya, C. (2019). Security Intelligence Cooperation and the Coordinated War on Terror among Nigeria's Security Agencies: Panacea to Stable National Security. Global Scientific Journal Publications: London; Vol. 7, Issue 7, July, 2019

Abiodun, T.F. (2016). An Appraisal of Nigeria's Counter-Terrorism Policy: The Case of Boko Haram. In Akinwumi, F.S., and Olaniyan, D.A. (Eds.) Global Perspectives in Education. Ibadan: His Lineage Publishing House. 145-155pp. ISBN 978-978-52551-4-0.

Achumba, I. C., Ighomereho, O. S and Akpor, M. O. M (2013). Security Challenges in Nigeria and the Implications for Business Activities and Sustainable Development. Journal of Economics and Sustenance Development, Vol. 4, No. 2 pp. 79-99.

Aguda, A. (1991). The Military and Constitutionalism in Africa: The Nigerian Experience in State and Constitutionalism. Harare: Sage.

Apanisile, O.T. and Okunlola, O.C. (2014). An Emprical Analysis of Effects of Military Spending on Economic Growth in Nigeria: A Bound Testing Approach to Co-integration 1989-2013. Journal of Public Administration, Finance and Law, 6, 117-130.

Bove, V. and Brauner, J. (2016). The Demand for Military Expenditure in Authoritarian Regimes. Defence and Peace Economics, 27 (5), 609-625. doi:10.1080/10242694.2014.925325

CBSE Guide (2007-2017). Government Budget and the Economy. Retrieved from https://s3-apsoutheast-

Central Bank of Nigeria. Retrieved via: www.cenbank.org

Chartered Institute of Management Accountants (2006). Budgeting: Topic Gateway Series NO. 27. Retrieved from http://www.cimaglobal.com/Documents/Imported Documents/cig_tg_budgeting_mar08.pdf 
Chartered Institute of Management Accountants (CIMA) 2015.

Congressional Budget Office (2001). The Economic and Budget Outlook: An Update.

Felix, O. (2013). Poor Budgetary Performance: Causes and Implications for Development. European Journal of Accounting Auditing and Finance Research Vol.1, No.2, pp. 53-66, June 2013, Published by European Centre for Research Training and Development: United Kingdom.

Fukuyama, F. (2004). State-Building: Governance and World order in the 21st century, Itiaca: Cornell University Press.

Glamour, H (2005) Do private sector financial statement provides a suitable Public sector accounts? Downloaded via http/eb.uvie.ca/igi/report/ on 08/08/2003.

International Crisis Group. (2014). Curbing Violence in Nigeria (II): The Boko Haram Insurgency. Crisis Group Africa Report No 216.3 April 2014. 446

Johnson, I. E (1982). Public Sector Accounting and Financial Control. The Nigerian Accountant - ICAN 25(6) : $15-21$

Julius, E. N. (1992). National Security and Defense Expenditure in Africa: A Political and Economic Analysis. African Development, Vol. XVII, No. 4, pp. 5-28

Key, V.O. (1987). "The Lack of a Budgetary Theory.” In J.M. Shafritz and A.C. Hyde (eds.), Classics of Public Administration, 2nd ed. Reprinted from American Political Science Review. Chicago: Dorsey Press, 1987:116-122.

Lewis, V. B. (1952). "Toward a Theory of Budgeting." Public Administration Review, 12: 4354.

Library of Congress Country Studies (2018).

Lynn, N. B. and Wildavsky, A. (1990). Public Administration: The State of the Discipline. Chatham, NJ: Chatham House Publishers, pp. 228-255.

McKaughan, J. (2016). "Nigerian Defence Budget - A Critical Review - African Defence". Retrieved from the Military Archive 24 January, 2014.

Omitoogun, W. and Oduntan, T. (2006). Budgetting for the Military Sector in Africa: The Processes and Mechanisms of Control. SIPRI. Oxford University Press (2006), Great Clarendon Street, Oxford OX 26DP. 158-162. 
Journal DOI: 10.46654/ij.24889849

Vol. 6, Issue 7 (July, 2020) | www.ijaar.org

Sam, P. F., Aude, F., Pieter, W., and Siemon, W. (2016). Trends in World Military Expenditure. Stocholm International Peace Research Institute (SIPRI) fact sheet. Retrieved from www.sipri. org.

Suleiman, E.S. (2015). "The Nigerian budget process: Understanding monetary policy Series". No. 56. Central Bank of Nigeria

United States Armed Forces (2017). What is Military? Retrieved from http://www.military.com/joinarmed- forces/us-military-overview.html

Walker, M. (1920). Municipal Expenditures and Progressive Budget Theory. Best Practices and Mode. Sage Publications.

Walker, M. (1937). Progressive Public Expenditures Budget Theory. Sage Publications.

Wilson, B., 2014. Arms and Dimensions of National Security. Dublin. Stone-age Publishers. 